\title{
Opinions and Expectations of Parents on Integration of Mobile Technologies to Education and School Family Cooperation
}

\author{
https://doi.org/10.3991/ijim.v11i4.6791 \\ Fezile Ozdamli \\ Near East University, Education Faculty, Cyprus \\ fezile.ozdamli@neu.edu.tr \\ Ezgi Pelin Yildiz \\ Near East University, Education Faculty, Cyprus \\ ezgipelin.yildiz@neu.edu.tr
}

\begin{abstract}
This study underlines the importance of mobile technologies in school family cooperation process. The aim is to specify expectations from mobile technologies and parent's opinions and capacity of mobile learning whose children attend to elementary and primary schools at Nicosia, TRNC. In this study which is conducted in a survey model frame, 790 parents involved in the study group to specify parent's level of using mobile tools, their opinions on usage of mobile devices in an educational purpose and on improvement of school-family cooperation with mobile technologies.In the study, a 2 dimensioned survey form used as data collection tool and gathered data processed appropiately to statistical teqniques with SPSS 21 package application. In data analysis, frequency, percentage values, t-test and Kruskal-Wallis tests are used. This is confirmed that parent's opinion on the usage of mobile devices in an educational pupose is generally positive. On the other hand, this is also clear that the parent's opinions on school-family cooperation and family participation with mobile technologies are positive. Parents stated that they can take education and information from relevant people of school with mobile technologies on child development and education. Also they specified the necessity of communicating with mobile technologies to take school-family cooperation to an advanced level.
\end{abstract}

Keywords—mobile technologies, mobile learnng, school-family cooperation

\section{Introduction}

Students learn several essential elements relating to their lives from parents. That reflects on their behaviours, beliefs and communication styles. According to Vural (2004) the processes of education of school and parent should complete and show consistency in order to achieve the determined aims of the school and socialization of the student (forming the desired human profile). 
As the result of the studies that have conducted on educational sciences, schoolparent coordination has a strong effect on academic success (Çelenk, 2003; Gümüşeli). The parent school relationship; cooperation, participation to the school processes and support to the school, is one of the important issues in each country (Starr 2003). The tendency on supporting the parents on taking more active missions in school activities with the importance of the parent in education is increasing gradually. The essentials of a successful education are based on school parent cooperation.

Changes in social life and experiences in human life bring together the change of education perception. In order to present more qualified education and raise the school success in the developed countries it has been handled that parents should take responsibility during the decision process of their children in the school. It's possible for the parents to establish a healthy communication via informing by the school about the development characteristics of their children and their success levels and gaining the positive effects on the student success for the parent participation (Aslanargun, 2007).

The aim of the trainers is increasing the school success of the students and their vision is integrating the best education which will provide them to be good citizens. In order to reach the mentioned aim and vision the cooperation of parent, school and environment is inevitable. Researches show that beginning the school-parent cooperation in the early ages and sustaining it during the school years, affect the behaviours of the children and increase their academic success positively (Starr 2003; Arslan and Nural, 2004).

Several obstacles on social economic and cultural features of the parent can affect negatively the performance of school-parent interaction. Parents having limited economic opportunities, having low education levels, lack of information about the interest, need and abilities of their children, low expectation level from the education, lack of information about their responsibilities on their children and how they are going to perform these, lack of time because of the crowded parent, believing the education is just the mission of the school, differences between the culture of parent and the school, restrictions in the school on the physical area, tools, personnel time and economical resources for the school and parent relations, negative acceptance of the parent when they have arrived to school, remaining aloof the school and negative experiences on their school life can be called as some of these limitations (Vural, 2004). Several methods can be used in order to prevent properties that will be able to effect parent-school interaction negatively; parent education is one of them. Interviews can be held, individual interview, classroom parent meetings, school parent meetings, special group meetings and written materials can be developed; individual education organizations can be arranged, conference, panel, seminar, meeting days and parent consultancy services can be provided. Besides these services information technologies can be used in order to increase parent-school cooperation. Nowadays most of the individuals own a mobile device and internet connection. School principals and teachers can increase their communications via these technologies. Also parents can be informed via mobile learning on parent-school cooperation.

Mobile learning is a method of learning that learner is stable or not in a place that is determined before or benefited from the learning opportunities that mobile technol- 
ogy has presented (Q'malley, Vavoula, Glew, Taylor, Sharples and Lefrere 2003). Mobile learning helps to develop the literacy and numeracy skills, to receive help and support on the areas that they have needed and to develop the ability of using information and communication technologies (Attewell, 2004). The education activities can be arranged for the issues that the parents needed via mobile learning devices (cell phones, PDA, iPhone, iPad, etc.) or social networking sites (facebook, twitter, blogs, etc.) especially the ones that increase the parent-school cooperation. Also mobile learning can be added to the activities that are done with the students and the motivation of the student can be increased accordingly. In the research of Ozdamli (2011) which has held in North Cyprus it has found that teachers are eager to use mobile learning applications in order to support the traditional learning methods.

A simple form of communication established between mobile communication devices and personal computers thanks to the development of today's internet technologies and computers with wireless connectivity. This change also introduced that mobile learning again can be used effectively in distance learning applications (Taleb \& Sohrabi, 2012). If we are to sort out the advantages of mobile learning; a) Life-long learning b) Implicit learning c) Learning in immediate needs d) Time and place independent learning e) Adjusted learning according to the location and conditions (Fadare, Aladeselu, Ekuobase, Aboderin \& Kumuyi, 2013).

Soykan and Uzunboylu (2015), according to the investigation on the search engines including the years between 2009 and 2014 (May), it can be seen that a lot of studies are included related to the mobile education. Mobile learning also increases the informal learning (Sharples, 2000; Vavoula and Sharples, 2009). In recent years the interest on the in informal learning increases accordingly. Informal learning is also supported by the technology. Mobile devices have the capacity of data collection and loading through connecting physical media. The mobile devices within the content of informal learning also support contextual, cooperative and constructivist learning (Patten et. al. 2006). Mobile devices have already integrated to daily life. This integration lets the users to use PDA and smart phones regularly. Whenever a need of mobile learning is required such devices are preferred. Mobile technologies will show an improvement day by day in terms of support to the informal learning, mobility and functionality (Clough, Jones, McAndrew and Scanlon, 2008). It's possible to arrange several kinds of activities based on parent-school cooperation and parent education and information by taking into consideration the defined advantages of the mobile learning especially creating a background for informal learning,

Application of technology based studies that make contribution for the school and parent cooperation shows necessity; the parent is primarily responsible for the education of the child in the societies. The function of the schools and other institutions follows the parent and the parent is supporting and complementary; because none of the institutions can provide love, trust, spirit, warm parent environment that he or she needed during the adolescence as his or her parent does (Çelik, 2005).

The present digital assistants PDA, electronic dictionaries, wireless laptops, iPod etc. not only serves for the trainers but also all kind of users. Mobile technologies are cheaper than other technologies and there are mobile for the users to learn anywhere, provides support on knowledge and learning styles, shows subsistence by providing 
personal resource reserve and can response for the daily needs on learning. Especially via internet compatible mobile phones have the opportunity to connect to the server fast, update private information, check daily controls, etc. (Hashemi and Babak, 2011; Uzunboylu and Ozdamli, 2014; Uzunboylu, Hursen, Ozuturk and Demirok, 2015).

If you integrate mobile technologies into school-parent cooperation, it is going to be possible to get benefited from mobile technologies on raising awareness for the parent in order to increase the academic success of the kid. The time problem has a great role which effects negatively to raise parent awareness on children and to prevent occurrence of parent-school cooperation. If we consider most of the individuals have mobile phones and internet connection, it is possible to overcome the obstacles mentioned herein. The determination of parent expectations and qualifications on mobile technology usage during education application and communication themselves constitutes the problem of this study.

\section{Related Researches}

Kim et al (2012) has developed game based mobile learning model and has researched its effectiveness. In the research that has held on 210 children between the ages 6-14 in India, it has observed that the children have performed metacognition behaviours by playing mathematical games which mobile learning justified the game based technologies without any intervention and instruction.

Shave et al (2012) have determined that even though there are difficulties in the applications in terms of self-control during learning activity, the mobile environments that mobile learning provided has the opportunity to support self-learning and has an important role on the self-actualization of the metacognition behaviours on the study that they have performed by dividing 67 students into two groups.

The computer literacy of the students and parents have investigated in the research within the Fatih Project with parents, Dinçer (2012) has found that the computer qualification of the parents are low. Also there is low but significant relation between the computer qualification of parents and children. It's thought that it is important to include the parents into this project since parents will support students' lessons and there is a significant relation between parents' and students' computer qualifications.

Özçınar and Ekizoğlu (2012) have presented Blog Based Parent Involvement Approach in order to increase parent participation in children education. It has presented that general parent meetings on determined issues is ineffective for school-parent cooperation and it has prevented to develop higher levels of behaviours. (Epstein, 1986; Çelik, 2005; Dyson, 2001).

Blau and Hameiri (2012) have defended web based school information systems are supportive on the teacher-parent communication in an early dated study. Daily and regular data transfer is thought to be supporting positive parent participation within the developed system.

Haktanır, Akgün, Karaman and Duman (2013) have handled mobile nursery school in their research. Mobile nursery school is a project which is developed in order to generalize the pre-school education by accessing to 36-72 month old children and 
their parents in the regions where the financially inadequate parents lived and to support children of these parents and to raise the conscious among the parents about the importance of pre-school education. Lots of small projects have started to response the needs of the female and children after such needs have determined. The mobile nursery school project which is conducted since 2003 has first begun in İstanbulKüçükçekmece-Kayabaşı. The most attraction aspect of the project was that the public of the village have met the pre-school education concept first time. The mobile nursery school which operates under the responsibility of Hayriye Andiçen Nursery School has achieved its purpose in the Village of Saraycik where it has arrived regularly and has caused to gain awareness on pre-school education and to open a nursery class (Üstündağ \& Haktanır, 2009). 927 children educated with 13 mobile classes in 10 cities during 2006-2007 academic year. Ankara, Antalya and Sakarya have added to list and it has reached to 22 mobile nursery classes within the academic year 20072008. As a result it has found that the children who have gone to mobile nursery school have positive difference in terms of cognitive, linguistic, social-emotional and kinaesthetic development zones and self-care skills.

The aim of this study is determining the views, qualifications of the parents in North Cyprus on mobile learning and increasing the parent-school cooperation with mobile technologies. Following sub-goals have developed in order to reach this objective:

- What level the parents can use the mobile devices?

- How are the expectations of the parents on using mobile devices with academic purposes?

- How are the expectations of the parents on providing parent-school cooperation via mobile technologies?

- How are the expectations of the parents on increasing participation via mobile technologies?

\section{Method}

In this research general scanning method has used in order to determine the views, qualifications of the parents in North Cyprus on mobile learning and increasing the parent-school cooperation with mobile technologies.

The study universe is the parent of the 4486 students in 4 nursery schools and 8 primary schools Nicosia, North Cyprus. The sample of the study is parent of 897 students studying at the schools of which is $20 \%$ of the total; but it has performed on 790 parents since the scale is completed incorrectly, the parents choose not to complete it. The feedback ratio of the scale is $89 \%$.

The parts that are used in the data collection tools are as the followings:

1. Personal İnformation Form (Demographic Data)

2. The Usage Level of Mobile Devices for the Parents

3. Parent Views on Academic Use of Mobile Devices

4. Parent-School Cooperation and Parent Participation wit Mobile Technologies. 
In the first part, personal information form, of the data collection tool; there is information about age, academic background, occupation, computer literacy, internet literacy, status about the usage of social networking websites. In the second part of the tool it is aimed to determine the level of status of using mobile phones of the parents. In the third part of the data collection tool; perception expressions for the use of the mobile phones with academic purposes are placed. There are 10 expressions in the questionnaire for the perception measurement form. The fourth part of the data collection tool; is formed with two groups: cooperation and parent participation. There is a questionnaire which contains parent views for increasing school-parent cooperation via mobile technologies within the cooperation context. The choices in the 11 item questionnaire are "Never", "Rarely", "Sometimes", "Usually", "Always". There is a questionnaire for parent views on parent participation with 9 items within the parent participation. The expressions in the $4^{\text {th }}$ part of this study have developed by getting utilization permit of "Director-Teacher-Parent Communication and Cooperation" scale of Atabey and Şahin.

The data is gathered by the research has analysed by using proper statistical techniques in accordance with the views of specialists in statistics field. Analysed data has interpreted by defining as tables and schemes. All score limits that is used on determining the levels of the parents on using mobile devices, the views on using mobile devices with academic purposes, the views on increasing school-parent cooperation and parent participation with mobile technologies.

\section{$4 \quad$ Results}

$49.1 \%$ of the participants are the fathers, $45.7 \%$ of the participants are the mothers and $5.2 \%$ of the participants are the other people (sister, brother, grandmother, nanny). The ages of the parents in the research sample; the younger is 17 and the older is 57 years old and the average is 35 years old. $46 \%$ of the parents are secondary school graduate, $35 \%$ of the parents are high school graduate and $13.4 \%$ of the parents are university, master and $\mathrm{PhD}$ graduate. $56.6 \%$ of the parent works in private sector, $23.2 \%$ of the parents are housewife, $\% 8.5$ is worker, $5.2 \%$ is public officer and the rest of them are academician and students. It is determined that $85.4 \%$ of the participants have computer, $89 \%$ of them are computer and internet literate and $73.7 \%$ of them have internet connection. According to these findings we can say most of the students are computer and internet literate. Also it is determined that $50.5 \%$ of the participants have internet connection on their mobile devices. This finding shows that half of the parents have internet connection on their mobile devices. $71.4 \%$ of the parents have determined that they are subscribed to the social networking websites such as Facebook, twitter etc. Based on the findings it is going to be possible to benefit from mobile technologies in order to create parent consciousness about the parentschool cooperation. 
Paper-Opinions and Expectations of Parents on Integration of Mobile Technologies to Education and ..

\subsection{The mobile devices that the parents have owned and usability level}

The analysis results on determining the possession status and usability levels of the mobile devices of the parents within the scope of this study has presented in the Table 1.

Table 1. The Possession Status and Usability Levels of the Mobile Devices of the Parents

\begin{tabular}{|l|c|c|c|c|}
\hline \multicolumn{1}{|c|}{ Devices } & \multicolumn{2}{c|}{ Possession Status } & \multicolumn{2}{c|}{ Usability Level } \\
\hline & $\boldsymbol{f}$ & $\boldsymbol{\%}$ & $\bar{X}$ & $\boldsymbol{S D}$ \\
\hline Smartphone & 564 & 99.4 & 4.27 & .77 \\
\hline Notebook & 459 & 58.1 & 3.18 & 1.53 \\
\hline MP3 player & 133 & 16.8 & 1.96 & 1.51 \\
\hline Tablets & 125 & 15.8 & 1.91 & 1.46 \\
\hline iPhone & 102 & 12.9 & 1.56 & 1.17 \\
\hline PSP-Xbox & 78 & 9.9 & 1.53 & 1.18 \\
\hline
\end{tabular}

The most possessed mobile devices of the parents are smartphones, notebooks and mp3 players. The parents have mentioned that they can use the smartphones "best", they can use notebook and smartphones "intermediate level" but they cannot use other devices very good.

\subsection{The Expectations of the Parents on Using Mobile Devices for Academic Purposes}

Mean and T-test analysis has held in order to determine the expectations of the parents on using mobile devices for academic purposes. The findings gathered from the analysis are below:

Table 2. Expectations on Using Mobile Devices for Academic Purposes

\begin{tabular}{|l|c|c|}
\hline & $X$ & SD \\
\hline Learning activities supported by the mobile devices can be effective for the students & 3.66 & 1.10 \\
\hline $\begin{array}{l}\text { Knowledge sharing can be held by communicating via chat programs with mobile } \\
\text { devices. }\end{array}$ & 3.63 & .99 \\
\hline Mobile learning applications can be used as support to the traditional education & 3.61 & .99 \\
\hline Mobile technology is an effective method to transfer the knowledge & 3.58 & 1.04 \\
\hline Mobile devices terminate the time and place restrictions & 3.56 & 1.10 \\
\hline $\begin{array}{l}\text { An effective learning environment can be created by sending, lecture notes and } \\
\text { homework via e-mail. }\end{array}$ & 3.51 & 1.06 \\
\hline Providing education techniques are not safe via mobile technologies & 2.81 & 1.03 \\
\hline General & $\mathbf{3 . 4 6}$ & $\mathbf{. 6 4}$ \\
\hline
\end{tabular}

Parents think that the learning activities that are supported via mobile devices are going to be effective. In addition according to the findings knowledge share can be 
performed via mobile technologies, they think it is effective to transfer the knowledge but it should be used as supportive to traditional education. The parents expect that an effective learning environment can be created by sharing the lecture notes and other classroom materials by mobile devices and mobile devices are going to terminate the restriction of time and place. Parents have not mentioned any positive view for providing education activities is not reliable.

As the result of the $\mathrm{T}$ test $(\mathrm{t}=-1.64, \mathrm{p}>0.05)$ analysis which is conducted in order to determine if the expectations of mother $(\bar{X}=3.42)$ and fathers $(\bar{X}=3.50)$ for mobile learning differentiated or not there is no significant difference.

According to the gathered findings it is found $(\mathrm{t}=5.01, \mathrm{p}<0.05)$ that the expectation of the parents who have internet connection $(\bar{X}=3.58)$ on their mobile devices is higher than the ones who has not $(\bar{X}=3.35)$. This finding makes us think that this is because the parents who uses internet with mobile technologies know the positive sides of it.

According to the findings gathered from the conducted analysis, it is found $(t=5.25$, $\mathrm{p}<0.05$ ) that the expectation of the parents who are subscribed to any social networking websites $(\bar{X}=3.54)$ is higher than the ones who are not $(\bar{X}=3.28)$. It can be said that social networking web sites are affecting the expectations for mobile learning positively $(\mathrm{t}=5.25, \mathrm{p}<0.05)$.

\subsection{The Expectation of the Parents for Providing School-Parent Cooperation Via Mobile Technologies}

Mean and T-test analysis has held in order to determine the expectations of the parents on using mobile devices for academic purposes. The findings gathered from the analysis are in Table 3.

If we are going to examine the parent expectations on mobile technologies that are providing school-parent cooperation, parents have determined that they can get information from the relating personnel about children development and training issues via mobile technologies. Also they determined that they can easily get information about the classroom activities of their children and they can provide school-parent cooperation easily via communicating mobile technologies. They have determined that when a decision is needed about their children and classroom, their ideas are going to be getting via mobile technologies. Generally the expectation of the parents on increasing the school-parent cooperation is determined as high. It is presented that there is no significant difference $(\mathrm{t}=.175, \mathrm{p}>0.05)$ between mother $(\bar{X}=3.52$, $\mathrm{SS}=.83)$ and father $(\bar{X}=3.51, \mathrm{SS}=.87)$ about the expectation of school-parent cooperation. We can say that the expectations of the fathers and mothers are similar to each other. There are significant differences between the ones who have internet connection $(\bar{X}=3.71, \mathrm{SS}=.82)$ and who have not $(\bar{X}=3.33, \mathrm{SS}=.83)$, on behalf of the ones who have internet connection on their mobile devices on the expectations of the parents for parent-school cooperation $(\mathrm{t}=6.43, \mathrm{p}<0.05)$. Similar to this there are sig- 
nificant difference between the ones who are subscribed to $\bar{X}=3.65, \mathrm{SS}=.60$ ) social networking websites and the ones who have not $(\bar{X}=3.20, \mathrm{SS}=.69)$, on behalf of the ones who are subscribed to social networking websites $(t=6.78, p<0.05)$. Based on the gathered findings, we can say that the situation of having internet connection on their mobile devices and using social networking websites affect their expectation of providing school-parent cooperation positively.

Table 3. The Expectation of the Parents for Providing School-Parent Cooperation Via Mobile Technologies

\begin{tabular}{|l|c|c|}
\hline & $X$ & SD \\
\hline $\begin{array}{l}\text { Information can be held on child development and training via mobile Tech- } \\
\text { nologies }\end{array}$ & 3.84 & 1.11 \\
\hline $\begin{array}{l}\text { I can easily get information about the activities which have held in the class- } \\
\text { room }\end{array}$ & 3.79 & 1.17 \\
\hline $\begin{array}{l}\text { Information can be held that I should support my child about his/her develop- } \\
\text { ment via internet and mobile technologies. }\end{array}$ & 3.68 & 1.16 \\
\hline $\begin{array}{l}\text { Common programs which contains teacher and mother-father activities via } \\
\text { internet and mobile technologies. }\end{array}$ & 3.55 & 1.18 \\
\hline $\begin{array}{l}\text { In order to increase the participation of fathers, communication via mobile } \\
\text { technologies can be provided. }\end{array}$ & 3.53 & 1.19 \\
\hline $\begin{array}{l}\text { I can share the studies that I do at home for the development and education of my } \\
\text { child and I can get support from other parents, directors and teachers. }\end{array}$ & 3.49 & 1.18 \\
\hline $\begin{array}{l}\text { The activities that are going to performed in order to create parent-school cooper- } \\
\text { ation and strengthen the relations }\end{array}$ & 3.46 & 1.22 \\
\hline $\begin{array}{l}\text { Our ideas are easily taken while taking a decision about children or classroom } \\
\text { via internet and mobile technologies }\end{array}$ & 3.46 & 1.20 \\
\hline $\begin{array}{l}\text { Meetings can be held with other parents when they have waited economic } \\
\text { support for material purchase. }\end{array}$ & 3.25 & 1.22 \\
\hline School-Parents Cooperation & 3.52 & .85 \\
\hline
\end{tabular}

\subsection{The Expectation of the Parents on Increasing the Parent Participation via Mobile Technologies}

The findings gathered by the analysis in order to determine the expectations for the parent participation via mobile technologies are presented in Table 4.

It is possible to say the expectations of the parents on increasing the parent participation via mobile technologies general positive. In addition parents have determined that they can communicate with the teacher in case of any problem about their children when they are at school, in case of any activity parent will be informed via mobile technologies and the teacher will share the reports that he/she has prepared about child development. The only point that the parents are indecisive is participating in the conferences held via mobile technologies. Parents haven't shown negative participation but they determined that they are indecisive. On the parent participation expectations, it has seen that there is no significant difference. According to the gathered 
data we can state that the parent participation expectations are positive $(\mathrm{t}=-.104$, $\mathrm{p}>0.05)$ and there is no significant difference between mother ; $\bar{X}=3.54, \mathrm{SS}=.91$ and father $(\bar{X}=3.55, \mathrm{SS}=.85)$. There are significant differences $(\mathrm{t}=6.73, \mathrm{p}>0.05)$ between the ones who have internet connection $(\bar{X}=3.77, \mathrm{SS}=.89)$ and who have not ( $\bar{X}=3.33, \mathrm{SS}=.93$ ) on behalf of the ones who have internet connection on their mobile devices on the expectations of the parents for parent-school cooperation. Similar to this there are significant difference between the ones who are subscribed to $(\bar{X}=$ $3.73, \mathrm{SS}=.88)$ social networking websites and the ones who have not $(\bar{X}=3.11$, $\mathrm{SS}=.92$ ), on behalf of the ones who are subscribed to social networking websites $(t=8.77, p<0.05)$. These findings can be interpreted that the parent participation expectations are affected positively by the status of having internet connection on their mobile devices and using social networking web sites.

Table 4. The Expectation of the Parents on Increasing the Parent Participation via Mobile Technologies

\begin{tabular}{|l|c|c|}
\hline & $X$ & SD \\
\hline $\begin{array}{l}\text { In case of any problem with my child I can do individual meetings with my child's } \\
\text { teacher. }\end{array}$ & 4.04 & 1.10 \\
\hline The teacher can make me attend classroom activities via mobile technologies & 3.62 & 1.24 \\
\hline $\begin{array}{l}\text { I can share the evaluation reports and views that the teacher prepared for the develop- } \\
\text { ment of my child via mobile technologies. }\end{array}$ & 3.57 & 1.37 \\
\hline $\begin{array}{l}\text { File share on the mobile digital environment about the activities that my child did in the } \\
\text { classroom can be more easily. }\end{array}$ & 3.57 & 1.23 \\
\hline I can share my child's problem with principals and teachers via mobile technologies. & 3.54 & 1.28 \\
\hline Notifications can be sent via mobile technologies & 3.52 & 1.28 \\
\hline $\begin{array}{l}\text { Participation for the decision process of education program can be provided via mobile } \\
\text { technologies. }\end{array}$ & 3.46 & 1.18 \\
\hline $\begin{array}{l}\text { By forming an online photograph album and panel information can be provided about the } \\
\text { activities }\end{array}$ & 3.40 & 1.29 \\
\hline I can participate in the conferences via mobile technologies. & 3.23 & 1.23 \\
\hline Parent Participation & 3.55 & .93 \\
\hline
\end{tabular}

\section{Discussion and Conclusion}

It was concluded that the great majority of parents included in the research had computers, they could use the computer and they had Internet connection and they could use the Internet. According to these findings, we can say that the great majority of the parents are computer and Internet literate. Again according to the results obtained, it was seen that half of parents the parents had Internet connection in their mobile devices. These results show that it can be communicate with the parents easily especially who had time shortage via Internet and mobile device for the improvement 
of parent-school collaboration. Most of the parents stated that they have memberships of the social networking sites; besides this, it is seen that half of the parents use social networking sites. This finding obtained is an important factor to be able to benefit from mobile technology about parent-school collaboration and especially in creating parent awareness. When mobile device belonging status of parents are examined, it is seen that the most used device is cell phone, and respectively laptops, smart phones, mp3 players (iPod, etc..), tablet computers, portable media players and personal digital assistants (PDAs) follow it. In general, parents have positive expectations about the usage of mobile devices for educational purposes. Parents think that mobile learning activities will be useful to use with the aim of supporting traditional education. In addition, in conclusion of the study, it is found that the expectations of the parents to improve the parent-school collaboration via mobile technologies are generally positive.

\section{References}

[1] Attewell J, \& Savill-Smith C (eds) (2004). Learning with mobile devices: research and development - a book of papers. London: Learning and Skills Development Agency. At http://www.lsda.org.uk, Retrieved February 15, 2017.

[2] Arslan, Ü., \& Nural, E. (2004). The Importance of School-Family Cooperation in PreSchool Education. Journal of National Education (162), 99-108.

[3] Aslanargun, E. (2007). A Screening Study on School-Family Cooperation and Student Achievement. Journal of Social Sciences 18, 119-135.

[4] Blau, I., \& Hameiri, M. (2012). Teachers-families online interactions and gender differences in parental involvement through school data system: Do mothers want to know more than fathers about their children? Computers and Education 59, 701-709. https://doi.org/10.1016/j.compedu.2012.03.012

[5] Clough, G., Jones, A.C., McAndrew, P., \& Scanlon, E. (2008). Informal learning with PDAs and smartphones. Journal of Computer Assisted Learning 24(5), pp. 359-371. doi:, http://dx.doi.org/10.1111/j.1365- 2729.2007.00268.x

[6] Çelenk, S. (2003). School Pre-requisites: School Family Support. Journal of Primary education-Online, 2(2), 28-34.

[7] Çelik, N. (2005). Problems in School-Family Relations. Marmara University Istanbul: Unpublished Master Thesis.

[8] Dinçer, S., Şenkal, O., \& Sezgin, M. (2012). Fatih Project Coordination of Teachers, Students and Parents and Computer Literacy Levels. At: http://ab.org.tr/ab13/bildiri/13.pdf Retrieved February 21, 2017.

[9] Dyson, L. L. 2001. "Home-School Communication and Expectation of Recent Chinese Immigrants." Canadian Journal of Education 26(4) 455-476. https://doi.org/10.2307/ $\underline{1602177}$

[10] Epstein, J. L. (1986). Parent involvement: Implications for limited-English-proficient students. In C. Simich-Dudgeon (Ed.), Issue of parent involvement and literacy (pp. 187203). Washington, DC: Trinity College.

[11] Fadare, O. G., Aladeselu, V. A., Ekuobase, G., Aboderin, O. S., \& Kumuyi, G. J. (2013). Adoption of Mobile Learning Among 3G-enabled handheld Users Using Extended Technology Acceptance Model. World Journal on Educational Technology, 5(3), 420-430. 
Paper-Opinions and Expectations of Parents on Integration of Mobile Technologies to Education and ...

[12] Gümüşeli, A. (2004). The Impact of Participation and Support on the Student Success. Private Schools Association Bulletin. 2(6), 14-17.

[13] Haktanır, G., Akgün E., \& Karaman G. (2013). Supporting the Development of Children by Running Collective Service Practices Lesson and Meb Mobile Kindergarten Project Together: Example of Peçenek Village. Journal of Kastamonu University Education Faculty, Volume:21 No:1, 69-82.

[14] Hashemi, M., \& Babak, G. (2011). Retraction notice to Using Mobile Phones in Language Learning/Teaching. Procedia - Social and Behavioral Sciences, 15, 2947-2951. https://doi.org/10.1016/j.sbspro.2011.04.220

[15] Huang, Y., Lin, Y., \& Cheng, S. (2010). Effectiveness of a mobile plant learning system in a science curriculum in Taiwanese elementary education. Computers \& Education, 54, 47-58. https://doi.org/10.1016/j.compedu.2009.07.006

[16] Ozçınar, Z., \& Ekizoğlu, N. (2013). Evaluation of a blog based parent involvement approach by parents. Computer \& Education, 66, 1-10. https://doi.org/10.1016/j.comp edu.2013.01.012

[17] Patten B., Arnedillo Sánchez I., \& Tangney B. (2006). Designing collaborative, constructionist and contextual applications for handheld devices. Computers \& Education 46, 294 308. https://doi.org/10.1016/j.compedu.2005.11.011

[18] O'Malley, C., Vavoula, G., Glew, J., Taylor, J., Sharples, M., and Lefrere, P. (2003). MOBIlearn WP4 Guidelines for learning/teaching/tutoring in a mobile environment. Web: http://telearn.archives-ouvertes.fr/hal-00696244/

[19] Sharples, M. (2000). The design of personal mobile technologies for lifelong learning. Computers \& Education, 34, 177-193. https://doi.org/10.1016/S0360-1315(99)00044-5

[20] Sharples, M., \& Vavoula, G. (2009).Lifelong Learning Organisers: Requirements for tools for supporting episodic and semantic learning. International Forum of Educational Technology \& Society (IFETS).

[21] Starr, L. (2003). A Dozen activities to Promote Parent Involvement. http://www.educationworld.com/a admin/admin1. Siteyi. It was accessed from: on 12.02 .2017

[22] Soykan, E., \& Uzunboylu, H. (2015). New trends on mobile learning area: The review of published articles on mobile learning in science direct database. World Journal on Educational Technology (WJET) 7,(1) 31-41. https://doi.org/10.18844/wjet.v7i1.22

[23] Uzunboylu, H., Hursen, C., Özütürk, G., \& Demirok, M. (2015). Determination of Students' Attitudes for Mobile Integrated EFL Classrooms in Higher Education Institutions and Scale Development. Journal of Universal Computer Science, 21(10), 1283-1296.

[24] Uzunboylu, H., \& Ozdamli F. (2014). M-Learning Adequacy and Perceptions of Students and Teachers in Secondary Schools. British Journal of Educational Technology. https://doi.org/10.1111/bjet.12136

[25] Üstündağ, A., \& Haktanır, G. (2009), Evaluation of the Effect of MEB Mobile Kindergarten Project on the Cognitive and Language Development of Children. International Participation 2. Oral Communication on Child Development and Education, 7-9 October 2009, Ankara.

[26] Taleb, Z., \& Sohrabi, A. (2012). Learning on the move: The use of mobile technology to support learning for university students. Procedia-Social and Behavioral Sciences, 69, 1102-1109. https://doi.org/10.1016/j.sbspro.2012.12.038

[27] Vural, B. (2004). Qualified classroom and stress-free training environment. Istanbul: Hayat Publishing. 
Paper-Opinions and Expectations of Parents on Integration of Mobile Technologies to Education and ..

\section{Authors}

Fezile Ozdamli is with the head of Department of Computer Education \& Instructional Technology, Near East University, P.O. Box: 99138, Nicosia, North Cyprus (email: fezile.ozdamli@neu.edu.tr)

Ezgi P. Yildiz is with the Department of Computer Education \& Instructional Technology, Near East University, P.O. Box: 99138, Nicosia, North Cyprus

Article submitted 21 February 2017. Published as resubmitted by the authors 04 April 2017. 